\title{
EFFECTS OF ASCORBIC ACID AND GLUCOSE APPLIED AS FOOD SUPPLEMENTS ON SELECTED INDICES OF SIBERIAN STURGEON (ACIPENSER BAERI BRANDT, 1858) CULTURE IN COOLING WATER
}

\author{
WPLYW DODATIKU DO PASZY KWASU ASKORBINOWEGO \\ Z GLUKOZĄ NA WYBRANE WSKAŹNIKI CHOWU JESIOTRA \\ SYBERYJSKIEGO (ACIPENSER BAERI BRANDT 1858) \\ HODOWANEGO W WODZIE POCHEODNICZEJ
}

\begin{abstract}
Department of Aquaculture, Agricultural University of Szczecin, Poland
\end{abstract}
Siberian sturgeon weighing $50 \pm 5 \mathrm{~g}$, cultured in cages stocked at 45 specimens $/ \mathrm{m}^{3}$ density and placed in cooling water, were fed Dan-ex 2545 trout feed for 112 days. Experimental treatments differed in the amount of ascorbic acid + glucose mixture $(1: 9)$ added to the feed. The mixture was applied, in individual treatments, in doses of $0 ; 1 ; 5$; and $10 \mathrm{~g} / \mathrm{kg}$ feed, corresponding to ascorbic acid doses of $0 ; 0.1$; 0.5 ; and $1 \mathrm{~g} / \mathrm{kg}$ feed. The highest mixture doses resulted in a significant increase in the fish body fat level; however, no significant effect on fish growth was observed.

\section{INTRODUCTION}

Vitamin $\mathrm{C}$ is one of the essential vitamins the importance of which in fish nutrition is well understood. The major role of vitamin $\mathrm{C}$ in the fish body is to reduce a metal molecule in metalloenzymes to activate them for reactions in the body. Vitamin $\mathrm{C}$ is responsible for, i.a., collagen and cartilaginous tissue build-up, healing of wounds and broken bones, strength of capillaries, erythrocyte maturation, and normal haemoglobin level maintenance. In addition, the vitamin is involved in detoxification, steride hydrolysis, and in hormone activity. Together with vitamin $\mathrm{E}$, vitamin $\mathrm{C}$ is a natural antioxidant in the fish body (Halver 
1995). The vitamin C demand by an organism is expressed at three levels: resistance to disease, growth maximisation, and heal wounding ability (Abramo and Lovell 1991). The feed vitamin $\mathrm{C}$ level at which the resistance to disease is obtained is several times that at which the maximum growth occurs (Halver 1995). Due to the fact that pure L-ascorbic acid is thermally unstable, other forms of ascorbic acid, e.g., vitamin $\mathrm{C}_{2}$ (L-ascorbyl-2-sulphate) (Dąbrowski and Kock 1989; Amerio et al. 1998a) and L-ascorbyl-2-polyphosphate are more and more frequently used in fish feeding, the latter most often marketed as a mixture of ascorbyl phosphates, e.g., Rovimix Stay C-25 (Amerio et al. 1998b). As the two vitamin $\mathrm{C}$ forms mentioned are expensive, an attempt was made in the work described to determine effects of a relatively inexpensive mixture of ascorbic acid and glucose, added to a commercial feed, on the basic indices of Siberian sturgeon culture efficiency, feed utilisation, and nutrient retention.

\section{MATERIAL AND METHODS}

The study, carried out within 24 June-14 October 1998 at the Department of Aquaculture's Fisheries Experimental Station (FES) situated next to the Dolna Odra power station at Nowe Czarnowo, involved $50 \mathrm{~g}( \pm 5 \mathrm{~g})$ individual weight Siberian sturgeon aged $0+$. The fish were kept in $1 \mathrm{~m}^{3}$ cages stocked with 45 individuals each.

The fish were offered Dan-ex 2545 trout feed (Dana Feed), containing 45.45\% crude protein, $24.03 \%$ fat, $16.23 \%$ carbohydrates, and $23.05 \mathrm{MJ} \cdot \mathrm{kg}^{-1}$ gross energy.

The fish were divided into 4 groups, each offered feed enriched with various doses of a vitamin formula (manufactured by Biowet) consisting of $1: 9$ mixture of ascorbic acid and glucose. The mixture doses applied were $0 ; 1 ; 5$; and $10 \mathrm{~g} \cdot \mathrm{kg}^{-1}$ feed, i.e., $0 ; 0.1 ; 0.5$; and $1 \mathrm{~g}$ ascorbic acid per $1 \mathrm{~kg}$ feed. Before its addition to the feed, the mixture was dissolved in $25 \mathrm{~cm}^{3}$ water. Once the solution was absorbed by the feed, the latter was offered to the fish. Each treatment was applied in triplicate. The daily food ration $(\mathrm{kg})$ was calculated from

$$
\mathrm{DFR}=\mathrm{MFR} n \mathrm{~W}^{0.8} / 100
$$

where:

DFR, daily food ration

MFR, metabolic food ration, as expressed in \% metabolic body weight $\left(\mathrm{W}^{0.8}\right)$;

$\mathrm{n}$, number of fish per cage;

$\mathrm{W}$, mean individual fish weight $(\mathrm{kg})$.

On the onset and at the end of the experimental feeding period, 4 individuals were picked from each treatment for assays (following total homogenisation) of \% dry matter (drying at $105^{\circ} \mathrm{C}$ for $12 \mathrm{~h}$ ), crude protein (Kjeltec 1026), lipids (Soxhlet ethyl ether extraction for $12 \mathrm{~h}$ ), and ash (combustion at $550^{\circ} \mathrm{C}$ for $12 \mathrm{~h}$ ). Identical methods were used 
for corresponding assays made on the feed; the carbohydrate content was calculated from the difference between the dry matter and the sum of crude protein, lipids, and ash contents. The feed gross energy level was calculated from the amount of energy contained in each component; the following conversion factors were used: $39.53 \mathrm{~kJ} \cdot \mathrm{g}^{-1}$ lipid; $23.63 \mathrm{~kJ} \cdot \mathrm{g}^{-1}$ crude protein; and $17.15 \mathrm{~kJ} \cdot \mathrm{g}^{-1}$ carbohydrates (Jobling 1994).

To determine changes in the basic culture efficiency indices and to adjust the amount of feed offered to the fish, all the individuals in each cage were weighed, to $0.05 \mathrm{~kg}$, at 14-d intervals. The control weighing data were used to calculate interim values of the food conversion ratio (FCR) and metabolic growth rate (MGR); the final weight data were applied to calculate apparent net protein utilisation (aNPU), energy retained (ER), and apparent lipids retained (aLR). To test for significance of differences between the treatments, LSD test at $\mathrm{P}=0.05$ was used.

Water temperature, dissolved oxygen content, and $\mathrm{pH}$ were recorded automatically Daily means and ranges of the environmental parameters are shown in Fig 1.

\section{RESULTS AND DISCUSSION}

During the period of the experiment, the daily mean cooling water temperature ranged within $14.9-30.1{ }^{\circ} \mathrm{C}$; the oxygen content and $\mathrm{pH}$ ranged within $2.2-11.9 \mathrm{mg} / \mathrm{dm}^{3}$ and 6.9-8.9, respectively (Figs. 1 a-c). As reported by Kolman et al. (1994) and Filipiak et al. (1997), the Siberian sturgeon culture thermal optimum is $20-25^{\circ} \mathrm{C}$. Thus, in the experiment discussed here, the water temperature conformed to the thermal requirements of the species during certain periods only (Fig. 1a). Nevertheless, it was only during the third stage of the experiment (22 July-5 August), when the lowest oxygen content (less than $3 \mathrm{mg} / \mathrm{m}^{3}$; Fig. 1b) was recorded in addition to the high water temperature, that the culture success was visibly poorer than during the remaining stages. That means that the Siberian sturgeon is rather elastic in its thermal requirements, provided the oxygen conditions meet the standard. Similarly, Micheev (1982) demonstrated that growth rate and food utilisation efficiency in the Siberian sturgeon culture depended on an appropriate water oxygenation.

The experimental water $\mathrm{pH}$ was a factor of a minor importance for the culture results. Basically, the $\mathrm{pH}$ values recorded can be regarded as falling within the species' culture optimum (Milstejn 1972).

The $100 \%$ survival arrived at is an evidence of favourable environmental conditions and feeding regime. 


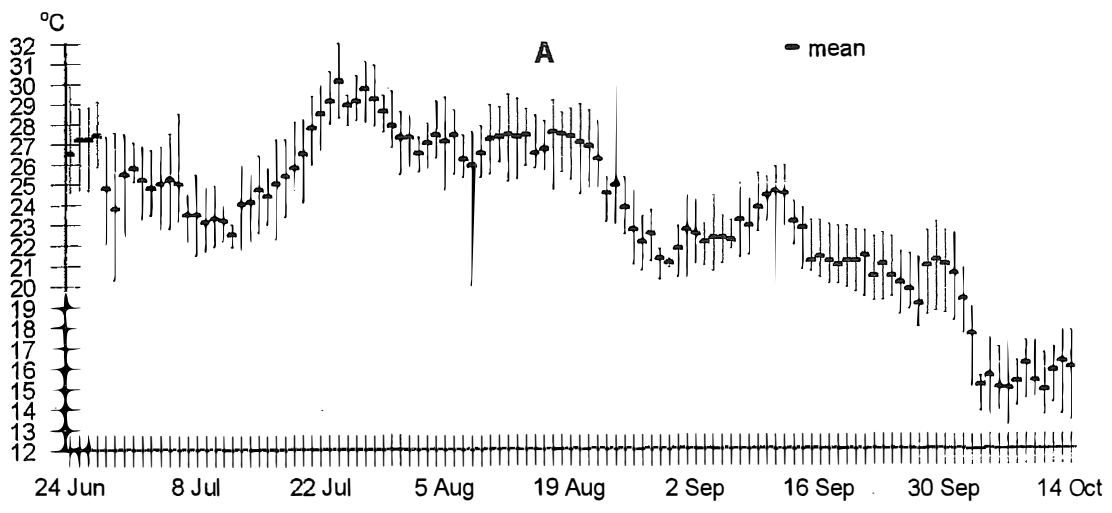

$\mathrm{mgO}_{2} / \mathrm{dm}^{3}$

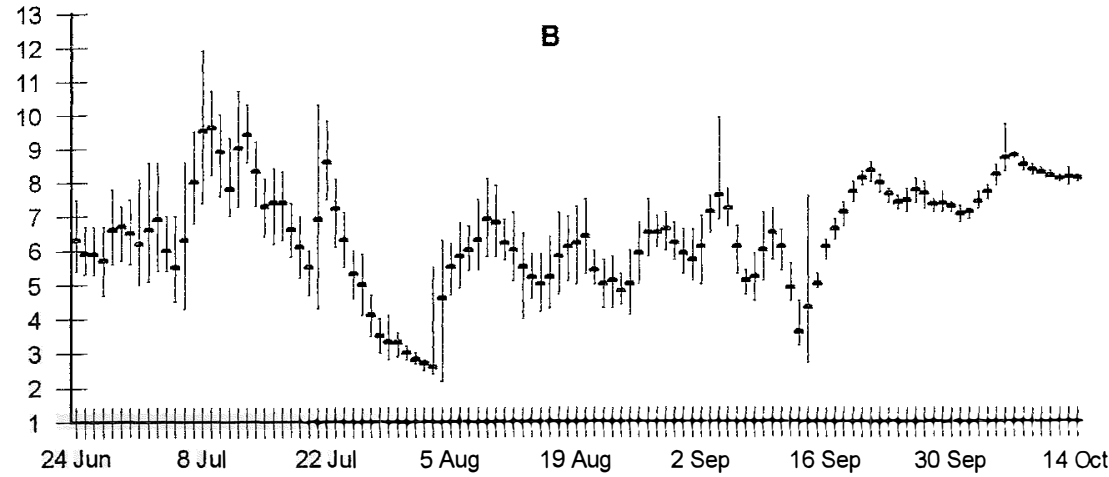

$\mathrm{pH}$

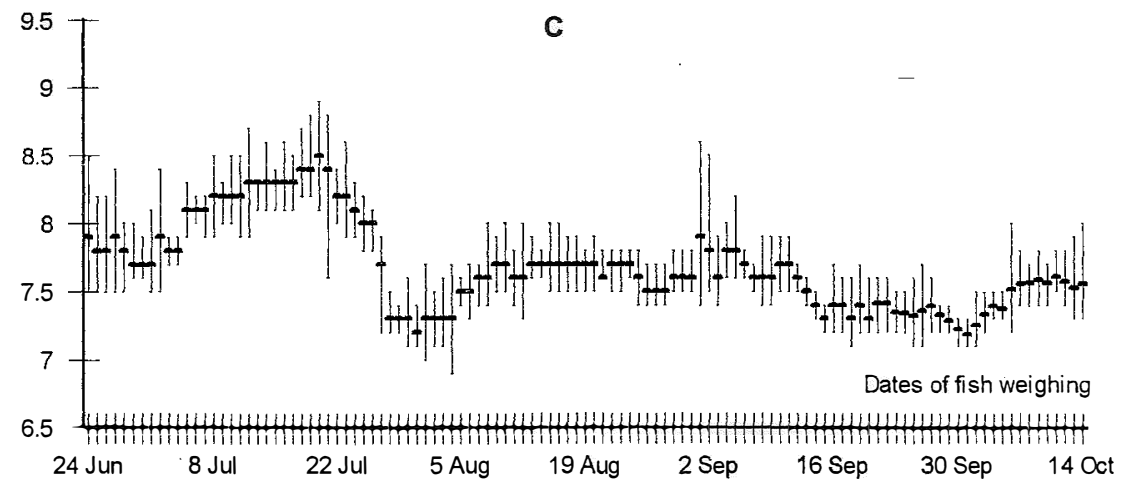

Fig. 1. Diel changes of temperature (A), oxygen content (B) and $\mathrm{pH}(\mathrm{C})$ in cooling water during the experiment 
The basic question addressed in this study was the effect of vitamin $\mathrm{C}+$ glucose on growth of and food utilisation by the sturgeon cultured. As shown by the data in Tabs. 1 and 2 , the vitamin formula doses applied produced no significant differences between the treatment and control growth rate parameter (MGR) and food utilisation (FCR). It can be thus concluded that vitamin $\mathrm{C}$ and glucose used as food supplements in doses of up to $10 \mathrm{~g} / \mathrm{kg}$ had no effect on changes in growth rate and food conversion ratio. A similar lack of any effect of L-ascorbyl-magnesium biphosphate (APM) and vitamin $\mathrm{C}_{2}$ on growth and food conversion rate was revealed in carp (Reddy and Ramesh 1996; Sadowski et al. 1999). With respect to acipenserids, Dąbrowski (1994) is of the opinion that sturgeons are capable of synthesising ascorbic acid due to the presence of gulonolacton oxidase. On the other hand, fish demand for vitamin $\mathrm{C}$ is known to be elevated in an intensive culture. The higher demand results from the presence of different stress factors in such cultures, e.g. high stocking densities or intensive feeding. Cases of skoliosis and lordosis have been recorded in carp kept in cooling water (Antychowicz and Nogajewski 1986).

Table 1

Mean individual weight, metabolic growth rate (MGR) and food conversion ratio (FCR) of Siberian sturgeon in each part of experiment

\begin{tabular}{|c|c|c|c|c|c|c|c|c|c|}
\hline \multirow{2}{*}{$\begin{array}{l}\text { Ascorbic acid } \\
\text { dose }\left(\mathrm{mg} \cdot \mathrm{kg}^{-1}\right)\end{array}$} & \multicolumn{9}{|c|}{ Dates of fish weighing } \\
\hline & Jun 24 & Jul 8 & Jul 22 & Aug 5 & Aug19 & Sep 2 & Sep 16 & Sep 30 & Oct 14 \\
\hline 0 & 49 & 83 & 126 & 137 & 169 & 224 & 287 & 384 & 460 \\
\hline 100 & 50 & 88 & 137 & 147 & 179 & 238 & 310 & 407 & 481 \\
\hline 500 & 50 & 91 & 142 & 153 & 186 & 243 & 313 & 413 & 489 \\
\hline 1000 & 51 & 89 & 137 & 144 & 179 & 236 & 312 & 402 & 481 \\
\hline \multicolumn{10}{|c|}{ MGR $\mathrm{g} \cdot\left(\mathrm{kg}^{0,8} \cdot \text { day }\right)^{-1}$} \\
\hline 0 & & $27.17^{\mathrm{a}}$ & $22.42^{\mathrm{a}}$ & $4.01^{\mathrm{a}}$ & $11.28^{\mathrm{a}}$ & $16.33^{\mathrm{a}}$ & $14.82^{\mathrm{a}}$ & $18.67^{\mathrm{a}}$ & $11.82^{\mathrm{a}}$ \\
\hline 100 & & $29.62^{\mathrm{a}}$ & $24.90^{\mathrm{a}}$ & $3.49^{\mathrm{a}}$ & $10.50^{\mathrm{a}}$ & $16.56^{\mathrm{a}}$ & $16.18^{\mathrm{a}}$ & $17.75^{\mathrm{a}}$ & $10.97^{\mathrm{a}}$ \\
\hline 500 & & $32.31^{\mathrm{a}}$ & $24.68^{\mathrm{a}}$ & $3.82^{\mathrm{a}}$ & $10.56^{\mathrm{a}}$ & $15.76^{\mathrm{a}}$ & $15.43^{\mathrm{a}}$ & $18.16^{\mathrm{a}}$ & $10.90^{\mathrm{a}}$ \\
\hline \multirow[t]{2}{*}{1000} & & $29.13^{\mathrm{a}}$ & $23.92^{\mathrm{a}}$ & $2.60^{\mathrm{a}}$ & $11.69^{\mathrm{a}}$ & $16.15^{\mathrm{a}}$ & $17.18^{\mathrm{a}}$ & $16.40^{\mathrm{a}}$ & $11.69^{\mathrm{a}}$ \\
\hline & SE & 2.24 & 1.49 & 1.16 & 0.75 & 0.65 & 1.24 & 0.70 & 0.73 \\
\hline \multicolumn{10}{|c|}{ FCR } \\
\hline 0 & & $1.12^{\mathrm{a}}$ & $1.34^{\mathrm{a}}$ & $5.90^{\mathrm{a}}$ & $2.26^{\mathrm{a}}$ & $1.23^{\mathrm{a}}$ & $1.36^{\mathrm{a}}$ & $1.07^{\mathrm{a}}$ & $1.71^{\mathrm{a}}$ \\
\hline 100 & & $1.11^{\mathrm{a}}$ & $1.21^{\mathrm{a}}$ & $6.83^{\mathrm{a}}$ & $2.40^{\mathrm{a}}$ & $1.21^{\mathrm{a}}$ & $1.24^{\mathrm{a}}$ & $1.14^{\mathrm{a}}$ & $1.83^{\mathrm{a}}$ \\
\hline 500 & & $0.94^{\mathrm{a}}$ & $1.23^{\mathrm{a}}$ & $5.64^{\mathrm{a}}$ & $2.39^{\mathrm{a}}$ & $1.27^{\mathrm{a}}$ & $1.30^{\mathrm{a}}$ & $1.10^{\mathrm{a}}$ & $1.85^{\mathrm{a}}$ \\
\hline \multirow[t]{2}{*}{1000} & & $1.04^{\mathrm{a}}$ & $1.27^{\mathrm{a}}$ & $9.39^{\mathrm{a}}$ & $2.14^{\mathrm{a}}$ & $1.25^{\mathrm{a}}$ & $1.21^{\mathrm{a}}$ & $1.22^{\mathrm{a}}$ & $1.73^{\mathrm{a}}$ \\
\hline & SE & 0.08 & 0.08 & 2.17 & 0.16 & 0.05 & 0.10 & 0.05 & 0.11 \\
\hline $\begin{array}{c}\text { Daily food } \\
\text { ration }\left(\% \mathrm{~W}^{08}\right)\end{array}$ & & 3.00 & 3.00 & 1.88 & 2.50 & 2.00 & 2.00 & 2.00 & 2.00 \\
\hline
\end{tabular}

Means not sharing identical superscript are significantly different $(\mathrm{P}<0.05)$ 
Table 2

Final values of metabolic growth rate (MGR), food conversion ratio (FCR), apparent net protein utilization (aNPU), apparent lipid retained (aLR), and energy retained (ER) of Siberian sturgeon fed food supplemented with different levels of ascorbic acid

\begin{tabular}{|c|c|c|c|c|c|}
\hline $\begin{array}{c}\text { Ascorbic acid dose } \\
\left(\mathrm{mg} \cdot \mathrm{kg}^{-1}\right)\end{array}$ & $\begin{array}{c}\mathrm{MGR}^{1} \\
\mathrm{~g} \cdot\left(\mathrm{kg}^{0.8} \cdot \mathrm{day}^{-1}\right.\end{array}$ & $\mathrm{FCR}^{2}$ & $\begin{array}{c}\mathrm{aNPU} \\
(\%)\end{array}$ & $\begin{array}{c}\mathrm{aLR}^{4} \\
(\%)\end{array}$ & $\begin{array}{c}\mathrm{ER}^{5} \\
(\%)\end{array}$ \\
\hline 0 & $15.67^{\mathrm{a}}$ & $1.47^{\mathrm{a}}$ & $21.72^{\mathrm{ab}}$ & $45.75^{\mathrm{a}}$ & $29.00^{\mathrm{a}}$ \\
100 & $15.65^{\mathrm{a}}$ & $1.47^{\mathrm{a}}$ & $22.34^{\mathrm{b}}$ & $48.56^{\mathrm{a}}$ & $30.45^{\mathrm{b}}$ \\
500 & $15.62^{\mathrm{a}}$ & $1.47^{\mathrm{a}}$ & $21.70^{\mathrm{ab}}$ & $54.75^{\mathrm{c}}$ & $32.70^{\mathrm{c}}$ \\
1000 & $15.63^{\mathrm{a}}$ & $1.47^{\mathrm{a}}$ & $21.24^{\mathrm{a}}$ & $62.32^{\mathrm{d}}$ & $35.61^{\mathrm{d}}$ \\
SE & 0.20 & 0.02 & 0.28 & 0.59 & 0.12 \\
\hline
\end{tabular}

${ }^{1}$ defined as a food ration expressed in $\mathrm{g} / \mathrm{kg}^{08}$ divided by FCR

${ }^{2}$ total food ration per unit of fish weight gain,

${ }^{3}$ amount of crude protein retained per unit of crude protein intake $\times 100$,

${ }^{4}$ amount of lipids retained per unit of lipids intake $\times 100$,

${ }^{5}$ amount of gross energy retained per unit of gross energy intake $\times 100$.

No such symptoms were observed in the present study, either in the control or in the treatment fish. Papp et al. (1997) found the absence of external signs of vitamin C deficiency in the control fish used in the experiment involving a sterlet $\times$ Siberian sturgeon hybrid. However, in a different experiment involving the hybrids weighing initially about $12 \mathrm{~g} / \mathrm{spec}$., Papp et al. (1995) recorded a slight enhancing effect of vitamin C supplied with feed on the fish growth rate.

In another experiment (the authors' own unpublished data) in which vitamin $\mathrm{C}$ solution was added to the Siberian sturgeon feed, a significant difference in growth rate compared with the control was recorded in the initial stage of the experiment only. That could be taken as indicating that the effect of vitamin $\mathrm{C}$ as a Siberian sturgeon feed supplement is stronger in smaller fish than those used in the experiment described in this paper.

Noteworthy are the data on lipid and energy retention, the values increasing with the vitamin + glucose dose ( $\mathrm{Tab} 2$ ). Application of vitamin $\mathrm{C}_{2}$ in a similar experiment involving carp resulted in a lower fat body content in the treatment fish, compared with the control (Sadowski et al. 1999).

\section{CONCLUSIONS}

To sum up the results of the experiment, it can be concluded that feed enrichment with a vitamin $\mathrm{C}+$ glucose formula does not affect the fish growth rate, nor does it result in a better food utilisation by the Siberian sturgeon. The vitamin supplement's only effect is a clear increase in the fish body fat content, accompanying slight differences in the crude 
protein content (Tab. 3). As shown by earlier studies, the sturgeon of a higher initial body fat content grow faster and better utilise their food in the second year of culture (Filipiak et al. 1998). Taking that aspect into account when assessing the results of the present study, it has to be concluded that vitamin $\mathrm{C}$ food supplementation enhances the Siberian sturgeon culture.

Table 3

Body chemical composition (\%) of Siberian sturgeon at the start and at the end of experiment

\begin{tabular}{|c|c|c|c|c|}
\hline $\begin{array}{c}\text { Ascorbic acid dose } \\
\left(\mathrm{mg} \cdot \mathrm{kg}^{-1}\right)\end{array}$ & Dry matter & Crude protein* & Lipids* & Ash $^{*}$ \\
\hline Start of experiment & 29.23 & $14.15^{\mathrm{a}}$ & $13.15^{\mathrm{a}}$ & 1.77 \\
\hline \multicolumn{5}{|l}{} \\
\hline End of experiment & 32.60 & $14.46^{\mathrm{b}}$ & $15.80^{\mathrm{b}}$ & 1.70 \\
100 & 34.09 & $14.85^{\mathrm{c}}$ & $16.71^{\mathrm{c}}$ & 1.75 \\
500 & 35.11 & $14.49^{\mathrm{b}}$ & $18.71^{\mathrm{d}}$ & 1.70 \\
1000 & 36.86 & $14.21^{\mathrm{a}}$ & $21.06^{\mathrm{e}}$ & 1.77 \\
\hline SE & & 0.03 & 0.09 & \\
\hline
\end{tabular}

* in wet weight

\section{REFERENCES}

Abramo L.D.R., R.T. Lovell, 1991: Aquaculture research needs for the year 2000: Fish and Crustacean Nutrition. World Aquaculture 22 (2): 57-61.

Amerio M., C. Ruggi, R.M. Rovelli, L. Volker, 1998a: Ascorbic acid availability from ascorbyl 2-polyphosphate and ascorbyl 2-sulfate in sea bass (Dicentrarchus labrax). Aquaculture, 159: 233-237.

Amerio M., C. Vignali, A. Italia, J. Gabaudan, 1998b: Metiterranean Sea Bream (Sparus curata) and Ascorbyl 2-polyphosphate: blood and liver concentration of ascorbic acid. VIII Intemational Symposium on nutrition and feeding of fish, Las Palmas de Gran Canaria, Spain, June 1-4, 1998.

Antychowicz J., R. Nogajewski, 1986: Choroby karpi i pstragów [Diseases of carp and trout].. Wyd. Akademii Rolniczo-Technicznej w Olsztynie. (In Polish).

Dąbrowski K, 1994: Primitive Actinopterigian fishes can synthesize ascorbic acid. Experientia, 50: 745-748.

Dąbrowski K, G. Kock, 1989 Absorption of ascorbic acid and ascorbic sulphate and their interaction with minerals in the digestive tract of rainbow trout (Oncorhynchus mykiss). Can. J. Fish. Aquat. Sci., 46: 1952-1957.

Filipiak J., J. Sadowski, R. Trzebiatowski, 1997: Feeding of Siberian sturgeon (Acipenser baeri) with different commercial feeds in cooling water, Zesz. Nauk. Akademii Rolniczej w Szczecinie, 179 (23): 5-13.

Filipiak J., J. Sadowski, R. Trzebiatowski, 1998: Effects of different conditions of wintering and feeding intensity on results of rearing the sibenan sturgeon (Acipenser baeri). Folia Univ. Agric. Stetin., 184, Piscaria (24): 25-34.

Halver J.E., 1995: Vitamin requirement study techniques. J. Appl. Ichthyol., 11 (3-4): 215-224.

Jobling M., 1994. Fish bioenergetics. Ed. Chapman \& Hall, London.

Kolman R., Szczepkowski M, Sidorowicz R., 1994: Chów jesiotra w stawach pstragowych [Rearing of sturgeon in trout ponds]. Materialy XIX Krajowej konferencji hodowców ryb łososiowatych [Proc. XIX Polish Conference of Salmonids Farmers], Wieżyca 5-7. 10.1994, Wydawnictwo Instytutu Rybactwa Śródlądowego: 67-72. (In Polish). 
Micheev V.P., 1982: Sadkovoe wyraščivanie tovamoj ryby [Cage reaning of fish]. Moskva. (In Russian).

Milstejn W.W., 1972: Osietrovye choziajstvo [Sturgeon rearing]. Moskva. (In Russian)

Papp G.Z., Z. Jeney, G. Jeney, 1995: Comparative studies on the effect of vitamin C feeding of European catfish (Silurus glanis L.) and sturgeon hybrid (Acipenser ruthenus L. $\times$ A. baeri L.). J. Appl. Ichthyol,, 11: $372-374$.

Papp G.Z., M. Saroglia, Z. G. Jeney, Jeney, G. Terova, 1997: Effects of vitamin C on collagen status of sturgeon hybrid (Acipenser ruthemus L. $\times$ Acipenser baeri L.). III International Symposium on Sturgeon, Piacenza, Italy, July 8-11 1997. Booklet of abstracts.

Reddy H.R., Ramesh T.J., 1996: Dietary essentiality of ascorbic acid for common carp ('yprinus carpio L. Indian J. Exp. Biol., 34 (11): 1144-1146.

Sadowski J., J. Filipiak, R. Trzebiatowski, M. Plust, 1999: Preliminary studies on effects of diet enrichment with propiscin, bio-immuno, and ascorbyl sulphate on cage culture of carp (Cyprinus carpio L.) juveniles in cooling water. Folia Univ. Agric. Stetin., 192 Piscana (25): 71-77.

Wilson R.P., W.E. Poe, E.H. Robinson, 1989: Evaluation of L-ascorbyl-2-polyphosphate (AsPP) as a dietary ascorbic acid source for channel catfish. Aquaculture, 81: 129-136.

Jacek SADOWSKI, Rajmund TRZEBIATOWSKl, Magdalena WIELOPOLSKA

\title{
WPLYW DODATKU DO PASZY KWASU ASKORBINOWEGO Z GLUKOZA NA WYBRANE WSKAŹNIKI CHOWU JESIOTRA SYBERYJSKIEGO (ACIPENCER BAERI BRANDT 1858) HODOWANEGO W WODZIE POCHLODNICZEJ
}

\section{STRESZCZENIE}

W doświadczeniu przeprowadzonym w okresic 112 dni w Rybackiej Stacji Doświadczalnej w Nowym Czamowie jesiotry żywiono paszą Dan-ex 2545 firmy Dana Feed (o zawartości 45,54\% białka ogólnego, 24,03\% thuszczu 16,23\% węglowodanów i 23,05 MJ energii brutto). Warianty doświadczalne różniły się ilością dodawanej do paszy mieszaniny kwasu askorbinowego i glukozy (1:9). Dawka ta wynosiła $0 ; 1 ; 5 ; 10 \mathrm{~g}^{\cdot \mathrm{kg}^{-1}}$ paszy co odpowiadało dawce kwasu askorbinowego $0,0,1 ; 0,5 \mathrm{i} 1 \mathrm{~g}^{\mathrm{kg}} \mathrm{kg}^{-1}$ paszy. Materiał doświadczalny stanowily ryby w wieku $0+\mathrm{o}$ średniej masie jednostkowej $50 \mathrm{~g}( \pm 5 \mathrm{~g})$, hodowane w sadzach w obsadzie $45 \mathrm{szt} \cdot \mathrm{m}^{-3}$. W wyniku przeprowadzonych badań stwierdzono istotny wpływ wielkości stosowanej suplementacji paszy mieszanina kwasu askorbinowego i glukozy na zawartość tłuszczu w ciele ryb (najwyższa wartość $21,06 \%$ zanotowano przy dodatku $10 \mathrm{~g} \mathrm{~kg}^{-1}$ paszy, a najniższa $15,80 \%$ przy braku suplementacji), retencji energii i thuszczu. Natomiast nie stwierdzono wpływu na wartości wskaźnika retencji białka ogólnego (aNPU), współczynnika pokannowego (FCR) i metabolicznego tempa wzrostu (MGR). Na podstawie ww. wyników chowu stwierdzono, że dla jesiotrów syberyjskich o masie $50-500 \mathrm{~g} \cdot \mathrm{szt}^{-1}$ hodowanych $\mathrm{w}$ wodzie pochłodniczej suplementacja paszy mieszaniną witaminy $\mathrm{C}$ i glukozy nie wplywa korzystnie na wielkości uzyskiwanych wskaźników chowu, a jedynie powoduje otłuszczenie ciała ryb.

Author's address:

Received: 12 January 2000

\author{
Sadowski Jacek PhD \\ Department of Aquaculture, \\ Agricultural University of Szczecin \\ Kazimierza Królewicza 4, 71-550 Szczøcin, Poland \\ e-mail: sad@fish.ar.szczecin.pl
}

